\title{
Changes in spermatozoal chromatin packaging and susceptibility to oxidative challenge during aging
}

\author{
Ekaterina V. Zubkova, B.Sc., ${ }^{\mathrm{a}}$ Michael Wade, Ph.D., ${ }^{\mathrm{c}}$ and Bernard Robaire, Ph.D. ${ }^{\mathrm{b}}$ \\ ${ }^{\mathrm{a}}$ Departments of Pharmacology and Therapeutics and ${ }^{\mathrm{b}}$ Obstetrics and Gynecology, McGill University, Montreal, Quebec, \\ Canada; and ${ }^{\mathrm{c}}$ Environmental Health Science Bureau, Health Canada, Ottawa, Ontario, Canada
}

\begin{abstract}
Objective: Our goal was to test the hypothesis that spermatozoal chromatin packaging changes with age and that aging affects the susceptibility of spermatozoal DNA to oxidative damage.

Design: Laboratory study.

Setting: Academic facility.

Patient(s): Young (4 months) and old (21 months) Brown Norway rats.

Intervention(s): Spermatozoa were collected from the cauda epididymidis and were incubated in saline or $\mathrm{H}_{2} \mathrm{O}_{2}$. Main Outcome Measurement(s): Thiols levels, chromatin condensation, DNA susceptibility to acid-induced DNA denaturation, and DNA damage were evaluated using monobromobimane, chromomycin A3 (CMA3), acridine orange, and polymerase chain reaction, respectively.

Result(s): Spermatozoa from old rats had 25\% fewer disulfides but similar levels of free thiols as compared with young. The CMA3 staining was decreased by $13 \%$ with age. Levels of chromatin denaturation and DNA damage were similar in control groups. After exposure to oxidant, free thiols became oxidized by about $20 \%$ irrespective of age, but CMA3 staining changed little. The acridine orange assay, however, showed a trend for greater chromatin denaturation in spermatozoa from old rats after oxidant treatment. Furthermore, the DNA from spermatozoa of old rats was significantly more susceptible to developing DNA breaks and modification after oxidative challenge.
\end{abstract}

Conclusion(s): Spermatozoal chromatin packaging changes with aging and vulnerability to oxidative damage increases. (Fertil Steril ${ }^{\circledR}$ 2005;84(Suppl 2):1191-8. $\odot 2005$ by American Society for Reproductive Medicine.)

Key Words: Spermatozoa, chromatin, DNA, aging, oxidative challenge, rat, male reproductive system

Delayed parenthood is becoming an increasingly frequent option in today's society (1). While the decline in a woman's fertility with age is well studied and the consequences are well documented, it is only recently that issues relating to paternal age have started to be recognized (2). Epidemiologic studies on the effect of paternal age on offspring development have linked increased age with a number of genetic diseases, such as dwarfism, schizophrenia, Alzheimer's disease, cardiac defects, and cancers (3-7). Furthermore, both clinical studies and animal models show that the quality of spermatozoa and ejaculate change with advancing age, leading to decreased motility, abnormal morphology, decreased semen volume, and altered pregnancy outcome $(8-12)$. Such studies offer strong evidence that spermatozoa produced in aged individuals differ from those of young ones.

The role of spermatozoa is to successfully deliver an intact set of paternal chromosomes to the oocyte. Therefore, the integrity of a spermatozoon's DNA is a critical issue in male fertility. Several studies have shown that damaged DNA in

Received January 19, 2005; revised and accepted April 28, 2005.

These studies were funded by a grant from the Canadian Institutes for Health Research, Canada.

Reprint requests: Bernard Robaire, Ph.D., Department of Pharmacology and Therapeutics, McGill University, 3655 Promenade Sir William Osler, Montréal, QC, Canada H3G 1Y6 (FAX: 514-398-7120; E-mail: bernard.robaire@mcgill.ca). spermatozoa (such as increased fragmentation) is associated with decreased fertility or problems in the health of the offspring $(13,14)$.

There are several characteristics of spermatozoa and their microenvironment that protect chromatin integrity beyond what is seen in somatic tissues. The first level of defense is the privileged milieu created by the blood-testis and the blood-epididymis barriers, which have the potential of stopping many toxic and damaging agents from reaching spermatozoa (15-18). Additionally, fluids that bathe spermatozoa are rich in protective agents such as antioxidants (1922). Lastly, the highly compacted nature of the chromatin in the nuclei of spermatozoa provides additional protection.

One of the distinctive features of the structure of spermatozoa is the manner in which its chromatin is packaged. Spermatozoal DNA is packaged with protamines in place of somatic histones. This packaging greatly condenses the DNA, precluding RNA transcription, and results in lower accessibility to DNA-damaging agents (23). The stability of the nucleus is further enhanced by inter- and intramolecular protamine disulfide bonds that form during epididymal transit (24).

Protamines are unique to spermatozoa; they replace histones during spermatogenesis, when these proteins align lengthwise along the major groove of the DNA helix (25, 26), condensing it into a toroidal structure (27). During the process of spermatozoal maturation in the epididymis, the 
cysteines become progressively oxidized, thus forming interand intraprotamine disulfide bonds and further stabilizing the chromatin $(28,29)$. Numerous studies have shown an association between abnormal protamine deposition and infertility (30-32). However, the effect of aging on spermatozoa thiol bond formation and protamine deposition has never been investigated. Therefore, the first goal of our study is to evaluate what effect aging has on chromatin packaging in spermatozoa.

Assessing the damage induced by oxidative radicals in spermatozoa obtained from individuals of increasing age is of particular interest because spermatozoa encounter this type of stress during maturation in the male reproductive tract, upon ejaculation if leucocytes are present in semen (33, $34)$, during capacitation $(35,36)$, and during preparation for in vitro fertilization (37). Exposure to oxidative radicals can cause changes in spermatozoa motility, lipid and protein structure, and DNA integrity, and it strongly correlates with male-factor infertility (38-40). Therefore, we compared the susceptibility of chromatin from young and old males with oxidative challenge. We chose $\mathrm{H}_{2} \mathrm{O}_{2}$ as the oxidative stressor for its membrane permeability and readiness to form the highly reactive hydroxyl radical $\left(\mathrm{OH}^{\bullet}\right)$ (41).

Using the Brown Norway rat, a well-established model to study male reproductive aging (42-44), we found that aging correlates with changes in spermatozoal chromatin packaging and that the DNA becomes more susceptible to oxidative damage.

\section{MATERIALS AND METHODS Chemicals}

All chemicals were purchased from Sigma-Aldrich (St. Louis, $\mathrm{MO})$, except for monobromobimane $(\mathrm{mBBr})$, marketed as Thiolyte MB (Calbiochem, San Diego, CA), and the GeneAmp XL polymerase chain reaction (PCR) kit (Applied Biosystems, Foster City, CA), which includes the Thermus thermophilus DNA polymerase.

\section{Animals}

Adult male BN RIJ rats, aged 4 and 21 months, were obtained through the National Institutes on Aging (Bethesda, MD) from Harlan Sprague-Dawley (Indianapolis, IN). The rats were housed on a 14 hours light/10 hours dark cycle and were provided with food and water ad libitum. The animal studies were conducted in accordance with the principles and procedures outlined in "A Guide to the Care and Use of Experimental Animals" prepared by the Canadian Council on Animal Care (McGill protocol no. 4687).

\section{Collection of Spermatozoa}

Cauda epididymides from nonregressed testes were excised and finely chopped to release spermatozoa. To achieve maximum yields, spermatozoa were collected into a motility buffer (45). They were washed twice with hypotonic buffer
$(0.45 \% \mathrm{NaCl})$ to lyse any contaminating cells, then washed twice with PBS $\left(1 \mathrm{mmol} / \mathrm{L} \mathrm{KH}_{2} \mathrm{PO}_{4}, 10 \mathrm{mmol} / \mathrm{L} \mathrm{Na}_{2} \mathrm{HPO}_{4}\right.$, $137 \mathrm{mmol} / \mathrm{L} \mathrm{NaCl}, 2.7 \mathrm{mmol} / \mathrm{L} \mathrm{KCl}, \mathrm{pH} 7.0$ ) and finally divided into control, low-dose $\left(2.5 \mathrm{mmol} / \mathrm{L} \mathrm{H}_{2} \mathrm{O}_{2}\right)$, and highdose $\left(5 \mathrm{mmol} / \mathrm{L} \mathrm{H}_{2} \mathrm{O}_{2}\right)$ treatment groups. Each sample was then incubated for 1 hour at room temperature, washed twice with PBS, divided into vials containing approximately 5 million spermatozoa for the corresponding assays, and frozen at $-80^{\circ} \mathrm{C}$.

\section{Monobromobimane Thiol Labeling}

Thiol labeling was done according to Seligman et al. (46) with minor modifications. Briefly, spermatozoa from each treatment group were divided into two samples: one that was preincubated with $1 \mathrm{mmol} / \mathrm{L}$ of 1,4-dithiothreitol (DTT) to reduce disulfides to free thiols and one that was not. A $50-\mathrm{mmol} / \mathrm{L}$ stock solution of $\mathrm{mBBr}$ was prepared in acetonitrile and added to the spermatozoa suspension for a final $\mathrm{mBBr}$ concentration of $0.5 \mathrm{mmol} / \mathrm{L}$, and the sample was incubated in the dark for $10 \mathrm{~min}$. During this time, $\mathrm{mBBr}$, a fluorescent probe, reacted and bound to free thiols. Spermatozoa were then washed in PBS, sonicated on ice to detach heads from tails, and stored at $4^{\circ} \mathrm{C}$ (for 3 days) in the dark until analysis.

Analysis of spermatozoa was done using a fluorescenceactivated cell sorter (FACS) Vantage flow cytometer (BD Biosciences, Missisauga, Ontario, Canada) equipped with an argon ion laser (488-nm line excitation, for FSC and SSC profile). Blue fluorescence emission of $\mathrm{mBBr}$ was detected by 355 UV laser excitation and quantified (in arbitrary units) after passage through a 424/44 bandpass filter using Cellquest Pro (BD Biosciences). A total of 20,000 sperm were analyzed for each sample.

Disulfide concentrations were calculated by subtracting free thiols from total thiols for the corresponding sample and then dividing the value by two.

\section{Chromomycin A3 Staining}

Our flow cytometry-based chromomycin A3 (CMA3) quantification was adapted from the slide-based method (47). The CMA3 was dissolved in McIlvaine's buffer $(17 \mathrm{~mL}$ of 0.1 $\mathrm{mol} / \mathrm{L}$ citric acid mixed with $83 \mathrm{~mL}$ of $0.2 \mathrm{~mol} / \mathrm{L} \mathrm{Na}_{2} \mathrm{HPO}_{4}$ and $10 \mathrm{mmol} / \mathrm{L} \mathrm{MgCl}_{2}, \mathrm{pH}$ 7.0) to a concentration of 0.25 $\mathrm{mg} / \mathrm{mL}$. Chromatin was labeled as follows: Spermatozoa were incubated in the CMA3/McIlvaine's buffer for $20 \mathrm{~min}$ at $25^{\circ} \mathrm{C}$ in the dark. They were then washed in PBS, sonicated on ice to detach heads from tails, and stored at $4^{\circ} \mathrm{C}$ in the dark until analysis.

Flow cytometry analysis was done using a MoFlo High Performance Cell Sorter (DakoCytomation, Fort Collins, $\mathrm{CO}$ ) equipped with an I90 argon ion laser tuned to 457-nm line excitation (for FSC and SSC profile and also for excitation) and a 460/10 filter. The resulting fluorescence was detected with a 580/30 bandpass filter and quantified 
(in arbitrary units) using Summit v.3.1 software (DakoCytomation). A total of 20,000 sperm were analyzed for each sample.

\section{Acridine Orange Assay for Sperm DNA Denaturation}

To assess susceptibility of sperm DNA to acid-induced denaturation, the acridine orange ( $\mathrm{AO})$ assay was performed using a method described previously $(48,49)$. On the day of assay sperm samples were thawed and sonicated on ice, as discussed previously, to remove tails. A $300-\mu \mathrm{L}$ aliquot of spermatozoa in TNE $(10 \mathrm{mmol} / \mathrm{L}$ Tris, $150 \mathrm{mmol} / \mathrm{L} \mathrm{NaCl}$, and $1 \mathrm{mmol} / \mathrm{L}$ ethylenediaminetetraacetic acid (EDTA), $\mathrm{pH}$ 7.4) was mixed with $400 \mu \mathrm{L}$ of solution containing $0.08 \mathrm{~N}$ $\mathrm{HCl}, 150 \mathrm{mmol} / \mathrm{L} \mathrm{NaCl}$, and $0.1 \%$ Triton $\mathrm{X}-100, \mathrm{pH} \mathrm{1.2}$, and incubated at room temperature for $30 \mathrm{sec}$ to denature any uncondensed sperm DNA. Spermatozoa were then stained by the addition of $1.2 \mathrm{~mL}$ of $\mathrm{AO}$ solution $(200 \mathrm{mmol} / \mathrm{L}$ $\mathrm{Na}_{2} \mathrm{HPO}_{4}, 0.1 \mathrm{~mol} / \mathrm{L}$ citric acid buffer, $\mathrm{pH} 6.0,1 \mathrm{mmol} / \mathrm{L}$ EDTA, $150 \mathrm{mmol} / \mathrm{L} \mathrm{NaCl}$, and $6 \mu \mathrm{g} / \mathrm{mL} \mathrm{AO}$ ).

Stained spermatozoa were analyzed using a FACS Calibur flow cytometer (BD Biosciences) fitted with an argon ion laser (488-nm line excitation), and green fluorescence emission of AO was reflected by a 550 dichroic longpass filter and quantified after passage through a 530/30-nm bandpass filter. Red fluorescence of AO was detected after sequential passage through the 550 dichroic filter and a $670 \mathrm{~nm}$ longpass filter. Degree of spermatozoa DNA denaturation (DD) was determined by the intensity of red fluorescence (denatured DNA, arbitrary units) divided by the sum of red and green intensity and was calculated from raw data using WinList cytometry software (Verity Software, Topsham, $\mathrm{ME}$ ). Cells with abnormal DD within each sample were identified from the histogram plots of DD as the cells with DD values are clearly skewed higher than the tight cluster of DD values of normal cells. A total of 10,000 sperm were analyzed for each sample.

\section{Extraction of Genomic DNA}

Spermatozoa were resuspended in $1 \mathrm{~mL}$ STE buffer $(50$ $\mathrm{mmol} / \mathrm{L} \mathrm{NaCl}, 10 \mathrm{mmol} / \mathrm{L}$ Tris $\mathrm{HCl}, \mathrm{pH} 8.0,1 \mathrm{mmol} / \mathrm{L}$ EDTA) with $50 \mu \mathrm{L}$ of $20 \% \mathrm{SDS}, 40 \mu \mathrm{L}$ of $0.5 \mathrm{~mol} / \mathrm{L}$ DTT, and $200 \mathrm{U}$ of proteinase $\mathrm{K}$ and incubated at $55^{\circ} \mathrm{C}$ for 6 hour with shaking. Organic extraction was done by first mixing DNA with one volume phenol, followed by extraction with one volume of phenol/chloroform/isoamyl alcohol (25:24:1), followed by extraction with one volume chloroform. The DNA was then ethanol precipitated and resuspend in TE buffer (10 mmol/L Tris-Cl, $1 \mathrm{mmol} / \mathrm{L}$ EDTA, pH 7.4).

\section{Quantitative PCR}

Quantitative PCR was used to establish the extent of bulky DNA adducts and single/double strand breaks in genomic DNA. This assay works on the principle that increased bulky adduct formation or DNA breaks would prevent the poly- merase enzyme from completing amplification of the complimentary strands (50). Therefore, a sample with greater DNA damage would result in less PCR product being amplified. This is a powerful assay, which can be performed using nanogram quantities of DNA, and damage can be assessed in individual genes. By using primers for the clusterin gene and the mitochondrial genome, the quantitative PCR technique can be applied to both genomic and mitochondrial DNA.

The assay was done based on the method of Ayala-Torres et al. (50) Briefly, PCR conditions were as follows: $5 \mathrm{ng}$ template DNA, $3.3 \times$ buffer, $1 \mathrm{mg} / \mathrm{mL}$ bovine serum albumin (BSA), $10 \mathrm{mmol} / \mathrm{L} \mathrm{dNTP,} 25 \mathrm{mmol} / \mathrm{L} \mathrm{Mg}(\mathrm{OAc})_{2}, 10 \mathrm{pmol}$ of each primer, and one unit of Thermus thermophilus DNA polymerase. The PCR was initiated in a GeneAmp 2400 thermocycler (Perkin Elmer, Boston, MA) with a $75^{\circ} \mathrm{C}$ hotstart, followed by denaturation for 1 minute at $94^{\circ} \mathrm{C}$ and 25 cycles of the subsequent profile: 15 -second denaturation at $94^{\circ} \mathrm{C}$ and 12 -minute primer extension at $68^{\circ} \mathrm{C}$. The PCR was completed with a 10 -minute extension at $72^{\circ} \mathrm{C}$.

We applied these conditions to amplify both a $12.5-\mathrm{kb}$ clusterin gene fragment (using primers 5'-AGA CGG GTG AGA CAG CTG CAC CTT TTC-3' and 5' -CGA GAG CAT CAA GTG CAG GCA TTA GAG-3') and a 13.4-kb mitochondrial genome fragment (using primers 5'-GGC AAT TAA GAG TGG GAT GGA GCC AA-3' and $5^{\prime}$-AAA ATC CCC GCA AAC AAT GAC CAC CC-3'). Quantitative conditions were confirmed by amplifying samples containing 50\% DNA (data not shown).

\section{Statistical Analysis}

Data were initially analyzed using two-way analysis of variance (ANOVA) (for age and treatment), followed by the Holm-Sidak multiple comparison test for pairwise analysis $(P<.05)$. All statistics were done with SigmaStat (Version 3.0, Systat Software, Richmond, CA). The groups had $n=6$ each and results are expressed as mean \pm SEM.

\section{RESULTS \\ Monobromobimane Thiol Labeling}

A significant overall decrease in thiol quantity was found in spermatozoa from older animals (Fig. 1A). When we looked at the free thiols and disulfides separately, we found that there was no age-related change in free thiol status. Disulfides, on the other hand, showed a significant decrease in spermatozoa from old rats, where the mean $\mathrm{mBBr}$ fluorescence intensity decreased by more than $25 \%$.

After $\mathrm{H}_{2} \mathrm{O}_{2}$ treatment, total thiol levels continued to be lower in spermatozoa of aged animals, but only in the high $\mathrm{H}_{2} \mathrm{O}_{2}$ group (Fig. 1B). Free thiols significantly decreased after both low- and high-dose treatment; this decrease was not dose dependent and was a predictable result of treatment with an oxidant (Fig. 1B). 


\section{FIGURE 1}

Disulfide bonds, free thiol, and total thiol quantification by $\mathrm{mBBr}$ staining. Yellow bars represent young and blue bars represent old. Statistics key: $a=$ significant change between young control and old control; b = significant change between young control and young treated; $\mathrm{c}=$ significant change between old control and old treated; $d$ = significant change between young treated and old treated. Mean \pm SEM; $n=6$.

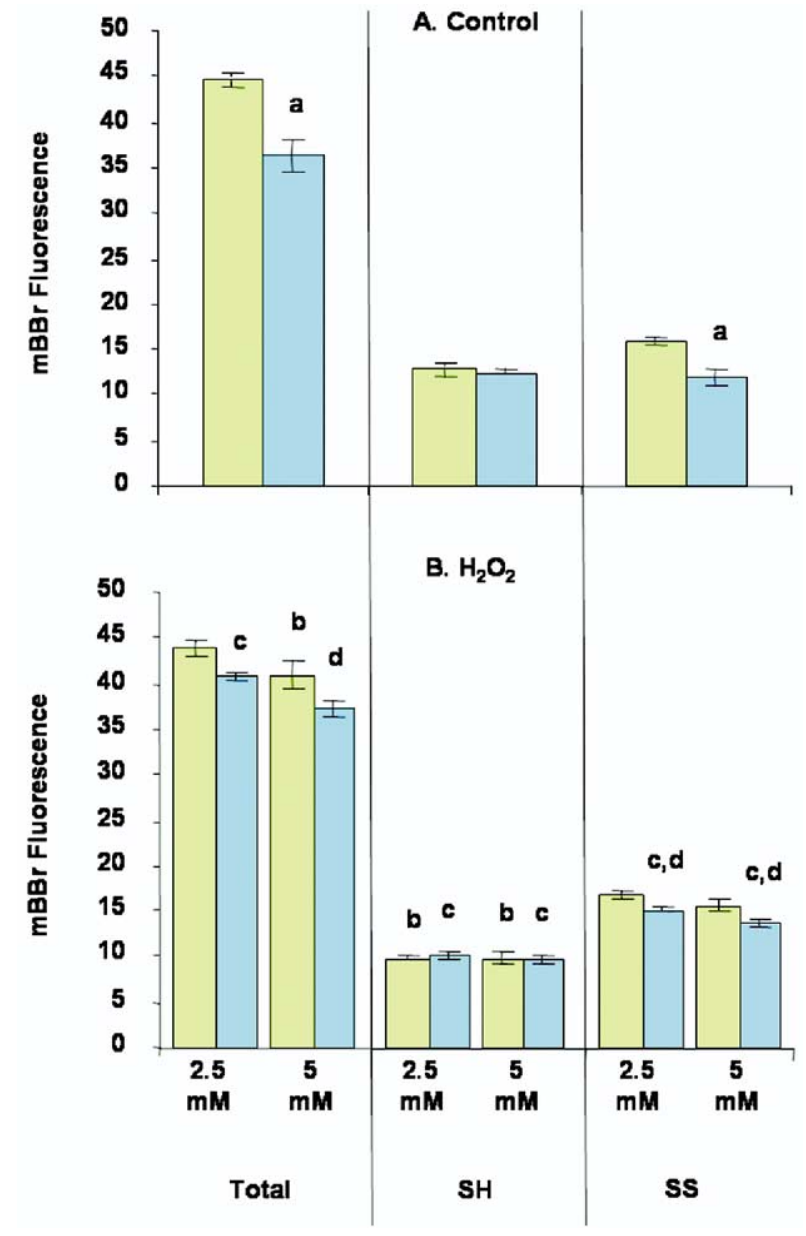

Zubkova. Effect of age on spermatozoal chromatin. Fertil Steril 2005.

As a result of free thiols becoming oxidized by $\mathrm{H}_{2} \mathrm{O}_{2}$, disulfide levels increased in all groups. This increase was significant in spermatozoa from old rats at both doses, but not significant in spermatozoa from young rats.

\section{Chromomycin A3 Labeling}

We found a remarkable difference in CMA3 labeling in spermatozoa collected from young and old rats (Fig. 2). Spermatozoa from young rats had significantly more CMA3 incorporation when compared with spermatozoa from old animals, suggesting either increased protamination or de- creased strength of protamine-DNA association or tighter chromatin structure with age. Incubation with $\mathrm{H}_{2} \mathrm{O}_{2}$ did not significantly alter CMA3 incorporation levels in any of the groups. Furthermore, the age-dependent difference was maintained, but it was statistically significant only in the control and low-dose groups.

\section{Acridine Orange Assay for Sperm DNA Denaturation}

Results from the sperm chromatin structure assay showed a clear dose-dependent increase in spermatozoa acid-induced DNA denaturation following incubation with $\mathrm{H}_{2} \mathrm{O}_{2}$ (Fig. 3).

Although there was no significant difference in the percentage of cells with abnormal DD between spermatozoa from young and old rats, we noticed a trend for increased chromatin denaturation in old rats when compared to young. Specifically, after the low-dose treatment, spermatozoa from old animals had a more than $5 \%$ greater percentage of abnormal DD, while at the high dose the increase in percentage of abnormal cells approached $10 \%$. Furthermore, the $P$ value for comparison between young and old decreased from 0.95 in controls to 0.35 in low dose to 0.11 in high dose, once again suggesting a trend for more dissociation with age.

\section{Quantitative PCR}

Before $\mathrm{H}_{2} \mathrm{O}_{2}$ treatment amplification of both DNA fragments remained constant regardless of the animals' age. After

\section{FIGURE 2}

Protamine association with sperm chromatin determined by CMA3 staining. Yellow bars represent young and blue bars represent old. Statistics key: $a=$ significant change between young control and old control; $b=$ significant change between young control and young treated; $\mathrm{c}=$ significant change between old control and old treated; $d$ = significant change between young treated and old treated. Mean \pm SEM; $n=6$.

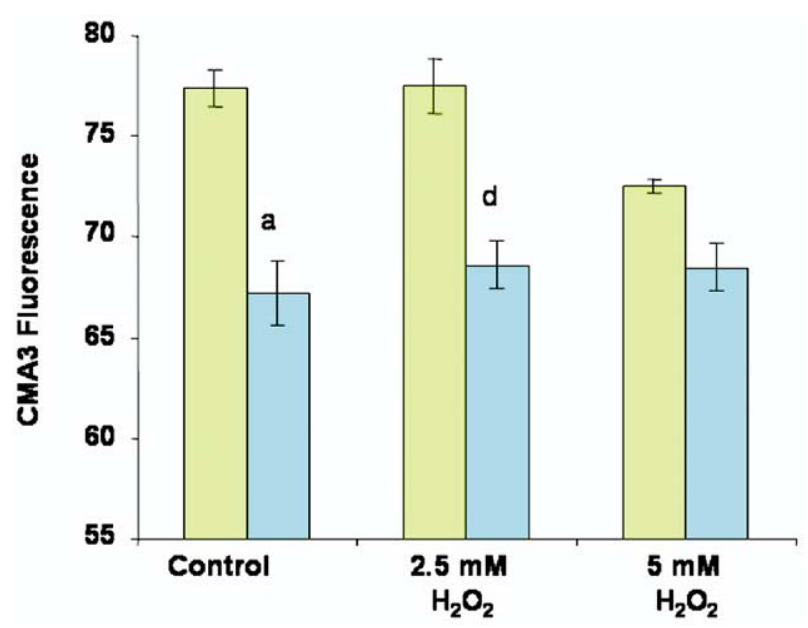

Zubkova. Effect of age on spermatozoal chromatin. Fertil Steril 2005. 


\section{FIGURE 3}

The proportion of sperm showing abnormal DNA denaturation (DD) as determined by the acridine orange assay. Values represent the mean proportion of sperm in each sample showing abnormally high levels of DD due to acid treatment (\% DNA denaturation). Yellow bars represent young and blue bars represent old. Statistics key: $\mathrm{a}=$ significant change between young control and old control; $b=$ significant change between young control and young treated; $c=$ significant change between old control and old treated; $d=$ significant change between young treated and old treated. Mean \pm SEM; $n=6$.

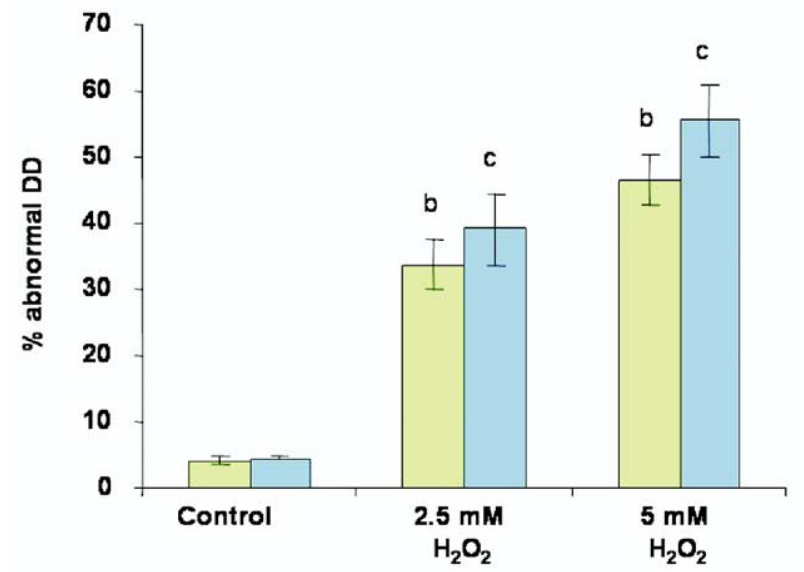

Zubkova. Effect of age on spermatozoal chromatin. Fertil Steril 2005.

$\mathrm{H}_{2} \mathrm{O}_{2}$, however, there was a clear age-dependant change in amplification.

Amplification of the clusterin gene from spermatozoa of young animals did not significantly change after treatment with $\mathrm{H}_{2} \mathrm{O}_{2}$ (Fig. 4A). In spermatozoa of old animals, however, there was a significant effect at the high $\mathrm{H}_{2} \mathrm{O}_{2}$ dose. Furthermore, DNA from old animals was significantly less amplified when compared to that from young rats after the high-dose $\mathrm{H}_{2} \mathrm{O}_{2}$ treatment $(P<.001)$. A significant interaction between age and treatment was found.

Mitochondrial DNA, on the other hand, was affected by $\mathrm{H}_{2} \mathrm{O}_{2}$ treatment in both young and old, causing dose-dependent decreased amplification of the genome (Fig. 4B). Furthermore, similarly to what was seen with the chromatin fragment, DNA from aged animals was significantly less amplified than that extracted from young at the high $\mathrm{H}_{2} \mathrm{O}_{2}$ dose.

\section{DISCUSSION}

In this study, we used a complimentary set of assays to understand the effect that aging has on spermatozoa chromatin structure. By combining assays that test for physio- logic processes (disulfide bond formation and chromatin protamination) with those that measure functional endpoints (DNA denaturation and damage), we found significant differences between spermatozoa from young and old rats.

The most dramatic change was a decrease of $25 \%$ in disulfide levels in old rats, implying a significant change in chromatin packaging. This change might be due to decreased intra- and interprotamine binding, thus potentially leaving spermatozoa of older rats less coiled and more vulnerable to

\section{FIGURE 4}

Detection of DNA breaks and oxidative modifications by PCR. Yellow bars represent young and blue bars represent old. Statistics key: $a=$ significant change between young control and old control; $b$ = significant change between young control and young treated; $c=$ significant change between old control and old treated; $d=$ significant change between young treated and old treated. Mean \pm SEM; $n=6$.

\section{A. Clusterin Gene}

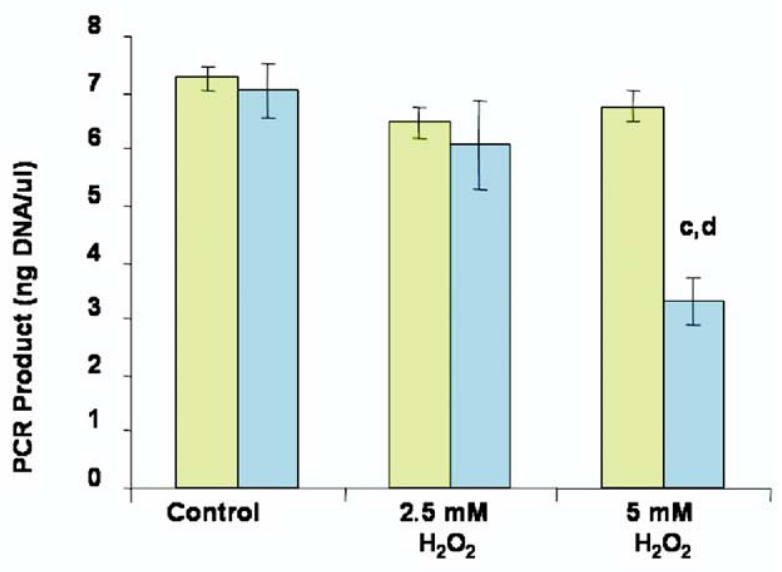

B. Mitochondrial DNA

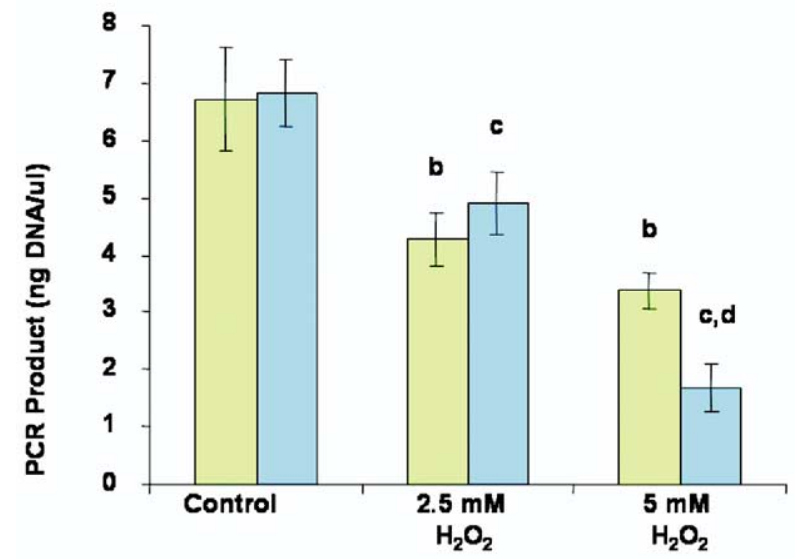

Zubkova. Effect of age on spermatozoal chromatin. Fertil Steril 2005. 
oxidative insult. This observation may be of particular significance because Zini et al. (51) showed that spermatozoa of infertile men have a higher level of free thiols and are more susceptible to DNA denaturation than those from fertile controls.

Incubation of spermatozoa with $\mathrm{H}_{2} \mathrm{O}_{2}$, an oxidant, resulted in thiols being converted from the reduced to the oxidized form. However, the thiol groups responded similarly in spermatozoa from both young and old rats, indicating that sensitivity of thiols to $\mathrm{H}_{2} \mathrm{O}_{2}$ is not altered with age.

Having established that there is a change in overall thiol levels with age, we wanted to see if this change was associated with alterations in chromatin protamination. The CMA3 assay is becoming more extensively used for evaluating sperm quality as part of male fertility assessment (52, 53). It provides an indirect measure of assessing protamines in sperm $(54,55)$, where CMA3 competes with protamines for chromatin binding $(47,56)$.

We found more CMA3 labeling in spermatozoa from young than from old rats in both control and $\mathrm{H}_{2} \mathrm{O}_{2}$-exposed groups. This was surprising because we expected spermatozoa from young rats to have more extensive protamination due to the higher concentration of disulfides detected in the chromatin. However, increased CMA3 incorporation can also occur if protamines are more easily displaced by the staining reagent or if chromatin has a looser structure (57). Our results indicate that the relationship between thiols, protamines, and CMA3 incorporation in older males is not as straightforward as in younger males.

To investigate if the altered DNA packaging in spermatozoa of aged rats affects chromatin condensation, spermatozoal chromatin structure was assessed using the acridine orange assay. This assay utilizes the differential fluorescence of the nucleic acid-binding dye AO, which fluoresces red or green when bound to either denatured or condensed chromatin, respectively. The degree of condensation of sperm nuclei is related to fertilizing potential $(58-62)$ and is a parameter indicative of toxicant-induced disruption of spermatogenesis (63).

When spermatozoa from young and old rats were compared, we saw no statistically significant difference in percentage of abnormal DD between the two age groups, either before or after $\mathrm{H}_{2} \mathrm{O}_{2}$ incubation. However, there was a clear trend toward greater decondensation in spermatozoa from old rats. A study done on rabbit spermatozoa supports this, as it also found that decondensation increased with age (64).

The increased chromatin dissociation after $\mathrm{H}_{2} \mathrm{O}_{2}$ treatment is most likely due to oxidant-induced DNA breaks. Owing to the condensed nature of the chromatin and the loss of most of their cytoplasm, mature spermatozoa lack appreciable levels of DNA repair (65-67). Knowing that $\mathrm{OH}^{\bullet}$ damages DNA by inducing base modification and strand breaks (41), we used the quantitative PCR assay to examine if the slight difference in percentage of abnormal DD that we saw be- tween young and old animals was indeed due to increased susceptibility to oxidative DNA modifications with age.

Quantitative amplification of the clusterin gene revealed that the level of DNA breaks was similar in young and old before $\mathrm{H}_{2} \mathrm{O}_{2}$ incubation. However, after oxidative stress, two very different responses emerged, where the chromatin from spermatozoa of aged rats showed a dramatic dose-dependent decrease in amplification. This supports our hypothesis that chromatin from spermatozoa of older rats is more sensitive to damaging agents than that of young ones. Furthermore, when these results were compared with those obtained from the mitochondrial genome of spermatozoa, DNA from both young and old rats showed a significant decrease in amplification after treatment, with a somewhat greater decrease at the higher $\mathrm{H}_{2} \mathrm{O}_{2}$ dose in the old rats. One possible explanation for the increased level of DNA damage in mitochondrial DNA is that it lacks protamines, proteins that act to protect spermatozoal DNA. This observation supports our findings regarding changes in chromatin packaging in the old rats.

Although only two studies have been published where the quantitative PCR technique was used in spermatozoa, our results correlate well with the previous report of significantly higher damage to the mitochondrial genome as opposed to the genomic DNA after $\mathrm{H}_{2} \mathrm{O}_{2}$ (68). It is of interest to note that in human spermatozoa, Sawyer et al. (69) showed much greater nuclear DNA damage than what was observed in our study, but this may be due to the fact that human spermatozoa are of lower overall quality than that found in other species (70). Additionally, human spermatozoa express both protamine 1 and protamine 2 (whereas rats have only protamine 1). It has been shown that the chromatin of spermatozoa from species expressing both protamines is more susceptible to decondensation (71); this property might also make it more susceptible to damage associated with oxidant exposure.

The changes in spermatozoal chromatin packaging observed with age could be due to a number of age-related changes in both testicular and epididymal function. Overall, the age-dependant accumulation of oxidative damage in an organism's DNA and proteins (72) can affect processes involved in the production of intact spermatozoa. In the testes, DNA mutations have been shown to accumulate in spermatozoa as a result of constant germ cell replication (73). A thickening of the basal membrane $(74,75)$ and a decrease in Sertoli cell numbers $(76,77)$ also occur in both humans and rats with age. Furthermore, we recently published our findings on changes in epididymal antioxidant capacity with age in rats (78) - these changes could also affect oxidative processes involved with chromatin compaction in spermatozoa.

In summary, we report here, for the first time, decreased CMA3 fluorescence and decreased disulfide formation in spermatozoa as animals age. These changes may be causing spermatozoa to become more vulnerable to oxidative damage with age and to develop more DNA breaks and oxidative 
modifications. Therefore, although males remain fertile well into old age, the quality of their spermatozoal chromatin declines, which in turn may have an impact on the wellbeing of their offspring.

Acknowledgments: We thank Marie-Hélène Lacombe, M.Sc., Eric Massicotte, B.Sc., and Martine Dupuis, M.Sc., for their excellent assistance with the flow cytometry and Dennis Sawyer, Ph.D., for help with the PCR protocol.

\section{REFERENCES}

1. van Balen F, Verdurmen JEE, Ketting E. Age, the desire to have a child and cumulative pregnancy rate. Hum Reprod 1997;12:623-7.

2. De La Rochebrochard E, McElreavey K, Thonneau P. Paternal age over 40 years: the "amber light" in the reproductive life of men? J Androl 2003;24:459-65.

3. Risch N, Reich EW, Wishnick MM, McCarthy JG. Spontaneous mutation and parental age in humans. Am J Hum Genet 1987;41:218-48.

4. Dalman C, Allebeck P. Paternal age and schizophrenia: further support for an association. Am J Psychiatry 2002;159:1591-2.

5. Bertram L, Busch R, Spiegl M, Lautenschlager NT, Muller U, Kurz A. Paternal age is a risk factor for Alzheimer disease in the absence of a major gene. Neurogenetics 1998;1:277-80.

6. Olshan AF, Schnitzer PG, Baird PA. Paternal age and the risk of congenital heart defects. Teratology 1994;50:80-4.

7. Hemminki K, Kyyronen P. Parental age and risk of sporadic and familial cancer in offspring: implications for germ cell mutagenesis. Epidemiology 1999;10:747-51.

8. Plas E, Berger P, Hermann M, Pfluger H. Effect of aging on male fertility? Exp Gerontol 2000;35:543-51.

9. Jung A, Schuppe H-C, Schill WB. Comparison of semen quality in older and younger men attending an andrology clinic. Andrologia 2002;34:116-22.

10. Kidd SA, Eskenazi B, Wyrobeck AJ. Effects of male age on semen quality and fertility: a review of the literature. Fertil Steril 2001;75: 237-48.

11. Serre V, Robaire B. Paternal age affects fertility and progeny outcome in the Brown Norway rat. Fertil Steril 1998;70:625-31.

12. Syntin P, Robaire B. Sperm structural and motility changes during aging in the Brown Norway rat. J Androl 2001;22:235-44.

13. Ahmadi A, Ng SC. Fertilizing ability of DNA-damaged spermatozoa. J Exp Zool 1999;284:696-704.

14. Host E, Lindenberg S, Smidt-Jensen S. The role of DNA strand breaks in human spermatozoa used for IVF and ICSI. Acta Obstet Gynecol Scand 2000;79:559-63.

15. Setchell BP, Voglmayr JK, Waites GM. A blood-testis barrier restricting passage from blood into rete testis fluid but not into lymph. J Physiol 1969;200:73-85.

16. Hinton BT, Howards SS. Permeability characteristics of the epithelium in the rat caput epididymidis. J Reprod Fertil 1981;63:95-9.

17. Okumura K, Lee IP, Dixon RL. Permeability of selected drugs and chemicals across the blood-testis barrier of the rat. J Pharmacol Exp Ther 1975;194:89-95.

18. Levy S, Robaire B. Segment-specific changes with age in the expression of junctional proteins and the permeability of the blood-epididymis barrier in rats. Biol Reprod 1999;60:1392-401.

19. Syntin P, Dacheux F, Druart X, Gatti JL, Okamura N, Dacheux JL. Characterization and identification of proteins secreted in the various regions of the adult boar epididymis. Biol Reprod 1996;55:956-74.

20. Fouchecourt S, Metayer S, Locatelli A, Dacheux F, Dacheux J-L. Stallion epididymal fluid proteome: qualitative and quantitative characterization; secretion and dynamic changes of major proteins. Biol Reprod 2000;62:1790-803

21. Hinton BT, Palladino MA, Rudolph D, Labus JC. The epididymis as protector of maturing spermatozoa. Reprod Fertil Dev 1995;7:731-45.
22. Zini A, Fischer MA, Mak V, Phang D, Jarvi K. Catalase-like and SOD-like activities in human seminal plasma. Urol Res 2002;30:321-23.

23. Ward WS, Coffey DS. DNA packaging and organization in mammalian spermatozoa: comparison with somatic cells. Biol Reprod 1991;44: 569-74.

24. Balhorn R. A model for the structure of chromatin in mammalian sperm. J Cell Biol 1982;93:298-305.

25. Prieto MC, Maki AH, Balhorn R. Analysis of DNA-protamine interactions by optical detection of magnetic resonance. Biochemistry 1997; 36:11944-51.

26. Fita I, Campos JL, Puigjaner LC, Subirana JA. X-ray diffraction study of DNA complexes with arginine peptides and their relation to nucleoprotamine structure. Mol Biol 1983;167:157-77.

27. Hud NV, Allen MJ, Downing KH, Lee J, Balhorn R. Identification of the elemental packing unit of DNA in mammalian sperm cells by atomic force microscopy. Biochem Biophys Res Commun 1993;193: $1347-54$.

28. Loir M, Lanneau M. Structural function of the basic nuclear proteins in ram spermatids. J Ultrastruct Res 1984;86:262-72.

29. Calvin HI, Bedford JM. Formation of disulphide bonds in the nucleus and accessory structures of mammalian spermatozoa during maturation in the epididymis. J Reprod Fertil 1971;13(Suppl 13):65-71.

30. Foresta C, Zorzi M, Rossato M, Varotto A. Sperm nuclear instability and staining with aniline blue: abnormal persistence of histones in spermatozoa in infertile men. Int J Androl 1992;15:330-7.

31. Belokopytova IA, Kostyleva EI, Tomilin AN, Vorob'ev VI. Human male infertility may be due to a decrease of the protamine $\mathrm{P} 2$ content in sperm chromatin. Mol Reprod Dev 1993;34:53-7.

32. Balhorn R, Reed S, Tanphaichitr N. Aberrant protamine 1/protamine 2 ratios in sperm of infertile human males. Experientia 1988;44:52-5.

33. Whittington K, Ford WC. Relative contribution of leukocytes and of spermatozoa to reactive oxygen species production in human sperm suspensions. Int J Androl 1999;22:229-35.

34. Plante M, de Lamirande E, Gagnon C. Reactive oxygen species released by activated neutrophils, but not by deficient spermatozoa, are sufficient to affect normal sperm motility. Fertil Steril 1994;62:387-93.

35. de Lamirande E, Gagnon C. Human sperm hyperactivation and capacitation as parts of an oxidative process. Free Radic Biol Med 1993;14: 157-66.

36. Aitken RJ, Buckingham DW, Harkiss D, Paterson M, Fisher H, Irvine DS. The extragenomic action of progesterone on human spermatozoa is influenced by redox regulated changes in tyrosine phosphorylation during capacitation. Mol Cell Endocrinol 1996;117:83-93.

37. Wang AW, Zhang H, Ikemoto I, Anderson DJ, Loughlin KR. Reactive oxygen species generation by seminal cells during cryopreservation. Urology 1997;49:921-5.

38. Wang X, Sharma RK, Sikka SC, Thomas AJ Jr, Falcone T, Agarwal A. Oxidative stress is associated with increased apoptosis leading to spermatozoa DNA damage in patients with male factor infertility. Fertil Steril 2003;80:531-5.

39. Agarwal A, Saleh RA, Bedaiwy MA. Role of reactive oxygen species in the pathophysiology of human reproduction. Fertil Steril 2003;79: $829-43$.

40. Padron OF, Brackett NL, Sharma RK, Kohn S, Lynn CM, Thomas AJ Jr, et al. Seminal reactive oxygen species, sperm motility and morphology in men with spinal cord injury. Fertil Steril 1997;67:115-20.

41. Halliwell B, Gutteridge JMC. Free radicals in biology and medicine. 3rd ed. New York: Oxford University Press, 2002.

42. Zirkin BR, Santulli R, Strandberg JD, Wright WW, Ewing LL. Testicular steroidogenesis in the aging Brown Norway rat. J Androl 1993; 14:118-23.

43. Wang C, Leung A, Sinha-Hikim AP. Reproductive aging in the male Brown-Norway rat: a model for the human. Endocrinology 1993;133: 2773-8.

44. Gruenewald DA, Naai MA, Hess DL, Matsumoto AM. The Brown Norway rat as a model of male reproductive aging: evidence for both primary and secondary testicular failure. J Gerontol 1994;49:B42-50. 
45. Slott VL, Suarez JD, Perreault SD. Rat sperm motility analysis: methodologic considerations. Reprod Toxicol 1991;5:449-58.

46. Seligman J, Kosower NS, Weissenberg R, Shalgi R. Thiol-disulfide status of human sperm proteins. J Reprod Fertil 1994;101:435-43.

47. Bianchi PG, Manicardi GC, Bizzaro D, Bianchi U, Sakkas D. Effect of deoxyribonucleic acid protamination on fluorochrome staining and in situ nick-translation of murine and human mature spermatozoa. Biol Reprod 1993;49:1083-8.

48. Foster WG, McMahon A, Rice DC. Sperm chromatin structure is altered in cynomolgus monkeys with environmentally relevant blood lead levels. Toxicol Ind Health 1996;12:723-35.

49. Evenson DP, Larson KL, Jost LK. Sperm chromatin structure assay: its clinical use for detecting sperm DNA fragmentation in male infertility and comparisons with other techniques. J Androl 2002;23:25-43.

50. Ayala-Torres S, Chen Y, Svoboda T, Rosenblatt J, Van Houten B. Analysis of gene-specific DNA damage and repair using quantitative polymerase chain reaction. Methods 2000;22:135-47.

51. Zini A, Kamal KM, Phang D. Free thiols in human spermatozoa: correlation with sperm DNA integrity. Urology 2001;58:80-4.

52. Iranpour FG, Nasr-Esfahni MH, Valojerdi MR, Al-Taraihi TM. Chromomycin A3 staining as a useful tool for evaluation of male fertility. J Assist Reprod Genet 2000;17:60-6.

53. Esterhuizen AD, Franken DR, Lourens JG, Van Zyl C, Muller II, Van Rooyen LH. Chromatin packaging as an indicator of human sperm dysfunction. J Assist Reprod Genet 2000;17:508-14.

54. Nasr-Esfahani MH, Razavi S, Mozdarani H, Mardani M, Azvagi H. Relationship between protamine deficiency with fertilization rate and incidence of sperm premature chromosomal condensation post-ICSI. Andrologia 2004;36:95-100.

55. Lolis D, Georgiou I, Syrrou M, Zikopoulos K, Konstantelli M, Messinis I. Chromomycin A3-staining as an indicator of protamine deficiency and fertilization. Int J Androl 1996;19:23-7.

56. Bizzaro D, Manicardi GC, Bianchi PG, Bianchi U, Mariethoz E, Sakkas D. In-situ competition between protamine and fluorochromes for sperm DNA. Mol Hum Reprod 1998;4:127-32.

57. Evenson D, Darzynkiewicz Z, Jost L, Janca F, Ballachey B. Changes in accessibility of DNA to various fluorochromes during spermatogenesis. Cytometry 1986;7:45-53.

58. Bungum M, Humaidan P, Spano M, Jepson K, Bungum L, Giwercman A. The predictive value of sperm chromatin structure assay (SCSA) parameters for the outcome of intrauterine insemination, IVF and ICSI. Hum Reprod 2004;19:1401-8.

59. Evenson D, Jost L. Sperm chromatin structure assay is useful for fertility assessment. Methods Cell Sci 2000;22:169-89.

60. Alvarez JG, Sharma RK, Ollero M, Saleh RA, Lopez MC, Thomas AJ $\mathrm{Jr}$, et al. Increased DNA damage in sperm from leukocytospermic semen samples as determined by the sperm chromatin structure assay. Fertil Steril 2002;78:319-29.
61. Evenson DP, Darzynkiewicz Z, Melamed MR. Relation of mammalian sperm chromatin heterogeneity to fertility. Science 1980;210:1131-3.

62. Evenson DP, Melamed MR. Rapid analysis of normal and abnormal cell types in human semen and testis biopsies by flow cytometry. J Histochem Cytochem 1983;31:248-53.

63. Evenson DP. Flow cytometry of acridine orange stained sperm is a rapid and practical method for monitoring occupational exposure to genotoxicants. Prog Clin Biol Res 1986;207:121-32.

64. Gogol P, Bochenek M, Smorag Z. Effect of rabbit age on sperm chromatin structure. Reprod Domest Anim 2002;37:92-5.

65. Sotomayor RE, Sega GA. Unscheduled DNA synthesis assay in mammalian spermatogenic cells: an update. Environ Mol Mutagen 2000;36: 255-65.

66. Cooper TG. Cytoplasmic droplets: the good, the bad or just confusing? Hum Reprod 2005;20:9-11.

67. Parvinen M, Hecht NB. Identification of living spermatogenic cells of the mouse by transillumination-phase contrast microscopic technique for "in situ" analyses of DNA polymerase activities. Histochemistry 1981;71:567-79.

68. Sawyer DE, Roman SD, Aitken RJ. Relative susceptibilites of mitocondrial and nuclear DNA to damage induced by hydrogen peroxide in two mouse germ cell lines. Redox Rep 2001;6:182-4.

69. Sawyer DE, Mercer BG, Wilkendt AM, Aitken RJ. Quantitative analysis of gene-specific DNA damage in human spermatozoa. Mutat Res 2003;529:21-34.

70. Aitken RJ, Sawyer D. The human spermatozoon—not waving but drowning. Adv Exp Med Biol 2003;518:85-98.

71. Perreault SD, Barbee RR, Elstein KH, Zucker RM, Keefer CL. Interspecies differences in the stability of mammalian sperm nuclei assessed in vivo by sperm microinjection and in vitro by flow cytometry. Biol Reprod 1988;39:157-67.

72. Holmes GE, Bernstein C, Bernstein H. Oxidative and other DNA damages as the basis of aging: a review. Mutat Res 1992;275:305-15.

73. Crow JF. The high spontaneous mutation rate: is it a health risk? Proc Natl Acad Sci USA 1997;94:8380-6.

74. Serre V, Robaire B. Segment-specific morphological changes in aging brown Norway rat epididymis. Biol Reprod 1998;58:497-513.

75. Dakouane M, Bicchieray L, Bergere M, Albert M, Vialard F, Selva J. A histomorphometric and cytogenetic study of testis from men 29-102 years old. Fertil Steril 2005;83:923-8.

76. Syed V, Hecht NB. Disruption of germ cell-Sertoli cell interactions leads to spermatogenic defects. Mol Cell Endocrinol 2002;186:155-7.

77. Paniagua R, Nistal M, Saez FJ, Fraile B. Ultrastructure of the aging human testis. J Electron Microsc Tech 1991;19:241-60.

78. Zubkova EV, Robaire B. Effect of glutathione depletion on antioxidant enzymes in the epididymis, seminal vesicles, and liver and on spermatozoa motility in the aging brown Norway rat. Biol Reprod 2004;71:1002-8. 